\title{
Physico-chemical changes and pest incidence associated with development of bael (Aegle marmelos Correa.) fruit
}

\begin{abstract}
This study investigated the nutritional changes and the effects of pests on the quality and development of Bael (Aegle marmelos Correa.) fruit. It has been found in the present study that there was a numbers of biochemical changes occurred during fruit development. Even, pest incidence in tender fruits on external surface and their subsequent infestation are also noted which resulted in economic loss in crop production system. The objectives of this study were to quantify different nutraceuticals compound, their origin and pest incidence in hard fruits like bael. Results revealed that fruit weight, fruit volume, fruit length and fruit diameter, seed weight and rind weight gradually increased from fruit set to maturity. Total soluble solid content (26.00B) and total sugars $(14.07 \%)$ were maximum at maturity. Carbohydrates and carotene contents gradually increased up to November. Due to development in mucilage (carotene dilution) and other soluble solids, carbohydrates slightly decreased in November after that it was gradually increased at harvest time. These nutraceuticals reflected double sigmoid growth curve in bael. There was no carotene development in first two months of fruit growth and it's development follows the trend as that of carbohydrates. Marmelosin $(850 \mathrm{mg} / 100 \mathrm{~g}$ pulp) and even poly-phenol $(4.03 \mathrm{~g} / 100 \mathrm{~g}$ pulp) content were found at the maximum in 90days growth and showed resistance against pest injury and stress. The protein content of bael was gradually increased (0$4.713 \%)$ up to December after which it decreased to a considerable level $(2.66 \%)$ at maturity. The pest incidence severity of bael fruit borer (Cryptophlebia ombrodelta) was $3(6-10 \%)$ and with moisture and nutrient stress the total damage of $40 \%$ was noticed under rain-fed ecosystem of Jharkhand, (Eastern) India.
\end{abstract}

Volume 7 Issue 6 - 2017

\author{
BR Jana, Md Idris, Madhumita Singh \\ ICAR-RCER, Research Centre, Makhana, Darbhanga Bihar, India
}

Correspondence: Bakul Ranjan Jana, Scientist and research fellow of bael project, ICAR-RCER, Research Center Ranchi, Jharkhand-834010, India, Email brjana.ars@gmail.com

Received: July 24, 2017 | Published: November 10, 2017

Keywords: bael, nutraceuticals polyphenol, fruit borer

\section{Introduction}

Bael (Aegle marmelos Correa.) is one of the most important minor fruit crops with medicinal and antioxidant properties grown in India from sea level to moderately high altitude. ${ }^{1}$ It belongs to the family Rutaceae and it's type of fruit is amphisarca. Sarkar et al. ${ }^{2}$ stated that it was originated from south East Asia. It flowers between April (next year) and May months, while harvesting is done in April. Bael fruits are very hardy and mature after $10-11$ months from fruit set. ${ }^{3}$ Fruit development stages (FDS) are associated with significant changes in carbohydrates, sugars and poly-phenol content. Bael contains appreciable amount of minerals like $\mathrm{Ca}, \mathrm{Mg}, \mathrm{Fe}$ and other elements which are very important for human health. Tender bael powder can be stored for long time, if harvested at 4-8months after fruit set. Tender bael fruits are cut into pieces, dried and ground into powder forms can be used in different pharmaceutical preparations. The mature bael pulp contains carotene and vitamins. Protein and secondary metabolites (poly-phenol) also changes during FDS up to November (green stage). ${ }^{4}$ It is useful in the treatment of diabetic patients due to high contents of mucilage and secondary metabolites as caumarin and mamelosin ${ }^{5} \mathrm{Bael}$ is also effective against cancer, cardiovascular diseases and ulcer. $^{6}$ Bael fruit borer and fruit fly incidence are associated with ovipositor on smooth green surfaces of fruits when poly-phenol content of the fruit decreases between 3-4months after fruit setting. The bael pulp and juices are excellent summer refresher Jana et al. 2014.7 Even RTS (ready to serve) and bael squash and slab are popular in north as well as south India. ${ }^{8}$ Fruit borer and fruit fly infestation at FDS have been found to responsible for major damages leading to fruit dropping after browning and economic yield losses under rain-fed ecosystem.

Singh et al. ${ }^{9}$ reported that bael fruit borer; Cryptophlebia ombrodelta (Tortricidae: Lepidoptera) is one of the major pest in eastern India infesting bael and tamarind. However, no systematic studies on biochemical changes and incidence in relation to polyphenol content at different growth stages of fruits development have not been reported. The present study, attempts to investigate the biochemical changes associated with fruit pulp during development as well as quantify the damages to fruits due to pest incidence in relation to poly-phenol content.

\section{Material and methods}

The experiment was conducted at Indian Council of Agriculture Research, Research Complex for Eastern Region, Research Centers, and Ranchi during May 2012- July 2013 to assess the biochemical changes and pests incidence at different growth stages of bael fruit development. Data were taken on TSS, acidity, reducing sugar, total sugar content of samples after one month interval from fruit setting to maturity. Fruit's physical parameters were collected by adopting standard methods. TSS was measured by Atago Digital Refract meter whereas reducing sugars and total sugars were calculated using Lane and Eynon method as modified by Ranganna. ${ }^{10}$ Acidity 
was estimated and expressed as citric acid equivalent. Protein was estimated using Lowry method and carbohydrates were measured by Anthrone method using preparation of diacidic samples. ${ }^{11}$ Polyphenol concentrations were measured spectro-photometrically at $760 \mathrm{~nm}$ using Folin-Ciocalteu reagent. Marmelosin content was determined using $5 \mathrm{~g}$ of fruit meso-carp and juice was extracted and homogenized using benzene afterwards and with UV-VIS Spectrophotometer. Samples were taken randomly in differentmonths from different plants maintaining in germplasm block in a row of ten plants. Data were statistically analyzed following Completely Randomized Design (CRD) with eleven treatments (month wise) with three replications in each treatment.

A 9-point scale ${ }^{12}$ was followed for recording the disease severity, where $1=0 \%, 2=1-5 \%, 3=6-10 \%, 4=11-20 \%, 5=21-30 \%, 6=31-40 \%$, $7=41-60 \%, 8=61-80 \%, 9=81-100 \%$. Ten fruits were collected in each replication scored individually in the laboratory taking into account the percentage fruit damaged by the pest. These grades were later converted into percentage disease/pest (severity) index (PDI/PPI) by using the formula given by Wheeler ${ }^{12} \mathrm{PPI}=($ Severity grade $\times$ no. of fruits $) \times 100 /$ Total no. of fruits observed $\times$ maximum grade

\section{Results and discussion}

\section{Fruit physical parameters}

The maximum fruit weight of $947.67 \mathrm{gm}$ was recorded in $11 \mathrm{months}$ old fruits from mature plants (9years), which was at par with fruits of February and March (Table 1). The results was in accordance with the findings of Kumar et al., ${ }^{13}$ Similar trend was also observed in the case of fruit volume and the maximum fruit volume of 900c.c. was obtained in April harvesting of 9 years old plants. Seeds and rinds of 2-3months were inseparable. Seed and rind weight gradually increased (seed $0.5-28.66 \mathrm{~g}$; rind $8.80-109.71 \mathrm{~g}$. till maturity (April, 2013 ) and attained maximum $28.66 \mathrm{~g}$ and $109.71 \mathrm{~g}$, seed weight and rind weight, respectively (Table 1). Specific gravity of the fruit did not havesignificant change throughout the growth period (0.85-0.99).

Table I Fruit morphological parameters at different stages of bael fruit development

\begin{tabular}{|c|c|c|c|c|c|c|c|}
\hline Treatments & $\begin{array}{l}\text { Fruit } \\
\text { weight(G) }\end{array}$ & $\begin{array}{l}\text { Fruit length } \\
(\mathrm{Cm})\end{array}$ & $\begin{array}{l}\text { Fruit } \\
\text { diameter(Cm) }\end{array}$ & $\begin{array}{l}\text { Fruit } \\
\text { Volume(C.C.) }\end{array}$ & $\begin{array}{l}\text { Specific } \\
\text { Gravity }\end{array}$ & Seed Weight(G) & $\begin{array}{l}\text { Rind } \\
\text { Weight(G) }\end{array}$ \\
\hline June & 3.25 & 2.29 & 1.43 & 3.11 & 0.95 & 0.00 & 0.00 \\
\hline July & 10.42 & 3.56 & 2.69 & 9.50 & 0.92 & 0.00 & 0.00 \\
\hline August & 130.00 & 8.03 & 6.05 & 115.00 & 0.88 & 0.5 & 8.80 \\
\hline September & 309.33 & 8.50 & 8.02 & 280.00 & 0.90 & 1.03 & 14.70 \\
\hline October & 635.33 & 10.06 & 10.1 & 573.33 & 0.90 & 1.33 & 23.93 \\
\hline November & 811.67 & 10.07 & 10.17 & 786.67 & 0.95 & 3 & 34.51 \\
\hline December & 815.67 & II.07 & 10.27 & 786.67 & 0.97 & 3.36 & 53.84 \\
\hline January & 823.00 & 11.28 & 10.34 & 796.67 & 0.99 & 12.06 & 77.19 \\
\hline February & 861.00 & 11.36 & 10.40 & 826.67 & 0.96 & 13.73 & 91.06 \\
\hline March & 874.67 & 11.47 & 11.35 & 850.00 & 0.97 & 19.53 & 101.78 \\
\hline April & 947.67 & 12.54 & 11.80 & 900.00 & 0.96 & 28.66 & $|09.7|$ \\
\hline CD at $5 \%$ & 188.33 & 1.78 & I.I I & I 68.26 & NS & I.7I & 8.63 \\
\hline
\end{tabular}

\section{Fruit biochemical parameters}

Table 2 revealed that the maximum TSS of $26.0^{\circ} \mathrm{B}$ was found in April (2013) harvested crop. TSS of the crop gradually increased from fruit set to maturity (5.73-26.00). The result was in accordance with the findings of Lakht-e-Zehra et al. ${ }^{14}$ They found that TSS of the bael pulp was $26.2+1.20^{\circ} \mathrm{B}$ in Karachi, Pakistan. Physiologically matured Bael in April that had reducing sugar and total sugar of $8.67 \%$ and $14.07 \%$, respectively. Bael acidity was less than that of guava $(<0.52)$. In our present study, it has been found that the acidity was increased (0.017-0.06 per cent) with the TSS of the crop till harvest.

\section{Bio-Chemical changes associated with maturity of bael}

The carbohydrates and carotene contents were observed at two distinct stages in their manifestations. First stage was between JuneOct (2012) (Figure 1) where the secondary metabolites gradually increased [carbohydrates $(34.45 \%)$ and carotene $60.45 \mathrm{mg} / 100 \mathrm{gm}$ pulp] where as in November (2012) both metabolites slightly decreased (carbohydrates $(31.44 \%)$ and Carotene $(46.69 \mathrm{mg} / 100 \mathrm{gm}$ pulp). According to Ladhha et al., ${ }^{15}$ the carbohydrates content of wild edible bael was $22.55 \pm 0.15 \mathrm{~g} / 100 \mathrm{~g}$. Roy ${ }^{16}$ found that maximum carbohydrates content of bael was $31.8 \%$. It might be due to formation of mucilage, sugar derivatives and other soluble solids from tannins and carbohydrates. This may be due to formation of mucilage, sugar derivatives and other soluble solids. In our study, it was observed that TSS of the crop for October and November are statistically at par i.e. $\mathrm{P}>0.5$ [Oct. $16.27^{\circ} \mathrm{B}$, Nov. $16.73^{\circ} \mathrm{B}$ ). The increase in mucilage content during the period of study agreed with the report of Singh et al. ${ }^{17}$ Later carbohydrates and carotene contents increased again [carbohydrates $(41.33 \%)$ and carotene $(61.78 \mathrm{mg} / 100 \mathrm{gm}$ pulp)] and covering initial lag phase in December 2012-January 2013. These results indicated double sigmoid growth pattern in bael pulp in respect to secondarymetabolites content during fruit development process. 
Table 2 Fruit biochemical characters as assessed at different stages of fruit development

\begin{tabular}{|c|c|c|c|c|c|}
\hline Treatments & TSS $\left({ }^{\circ} B\right)$ & Acidity (\%) & Reducing sugars (\%) & Non-reducing sugars (\%) & Total sugars (\%) \\
\hline June & 5.73 & 0.017 & 1.57 & 1.60 & 3.17 \\
\hline July & 7.07 & 0.018 & 1.79 & 2.07 & 3.86 \\
\hline August & 9.10 & 0.030 & 1.97 & 4.47 & 6.43 \\
\hline September & 12.77 & 0.027 & 2.83 & 5.57 & 8.40 \\
\hline October & 16.27 & 0.026 & 4.45 & 6.20 & 10.66 \\
\hline November & 16.73 & 0.026 & 6.24 & 4.97 & 11.21 \\
\hline December & 17.73 & 0.048 & 7.17 & 5.00 & 12.17 \\
\hline January & 19.47 & 0.053 & 8.17 & 5.03 & 13.20 \\
\hline February & 19.47 & 0.056 & 8.25 & 5.18 & 13.43 \\
\hline March & 20.80 & 0.060 & 8.39 & 5.11 & 13.50 \\
\hline April & 26.00 & 0.064 & 8.67 & 5.40 & 14.07 \\
\hline$C D$ at $5 \%$ & 2.22 & 0.008 & 1.82 & 2.07 & 0.61 \\
\hline
\end{tabular}

\section{Carbohydrates and Carotene development in Bael}

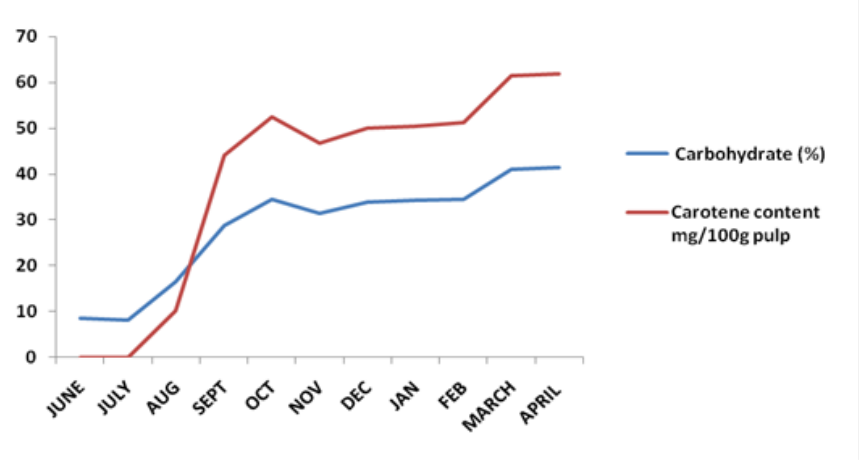

Figure I Changes in carbohydrates and carotene content in bael during fruit developmental stages (FDS).

A pattern of increase in protein content was as shown in Figure 2. It showed that protein content increased up to $4.712 \%$ in November, thereafter it decreased gradually and considerably $2.66 \%$. Gopalan ${ }^{18}$ and Roy et al. ${ }^{19}$ reported $1.80 \%$ protein content in bael fruit while Kausik et al. ${ }^{20}$ reported $3.30 \%$ in the same crop. Crude protein content fall progressively during fruit development but slightly increased at ripening. Kaur et al., ${ }^{4}$ reported $3.64 \%$ crude protein in matured bael. In the present study, marmelosin content was the maximum in 90days crop $(850 \mathrm{mg} / 100 \mathrm{gm}$ pulp) after which it gradually decreased to $9.88 \mathrm{mg} / 100 \mathrm{gm}$ pulp.

\section{Polyphenol content and pest incidence}

There are numbers of phenols which were associated with medicinal activities as well as defense system in relation to pest incidence. The maximum poly phenol $(4.03 \%)$ was recorded in 90days crop after which it gradually decreased to $1.47 \%(1470 \mathrm{mg} / 100 \mathrm{gm})$ at maturity in April (Figure 3). Kaur et al., ${ }^{4}$ reported that the bael fruit pulp contained 0.42 per cent $(420 \mathrm{mg} / 100 \mathrm{gm})$ of tannic acid. According to Roy ${ }^{16}$ the tannins in bael ranged from $3000-17500 \mathrm{mg} / 100 \mathrm{gm}$ pulp. Phenolics as tannic acid were in a range of 1755 to $3000 \mathrm{mg}$ per $100 \mathrm{~g}$ pulp and this agreed with Roy et al..$^{21}$ Total phenols were significantly lower at ripening stage as compared to green stage of maturity.

The reduction in poly-phenol began with the increase in sugar synthesis, which alters sugar: acid ratio and original acrid taste of the fruit gradually diminishes. After 90days of fruit development, fruit fly and fruit borer were observed. This result was in accordance with the findings of Singh et al., ${ }^{9}$ in their studies on bael products processing.

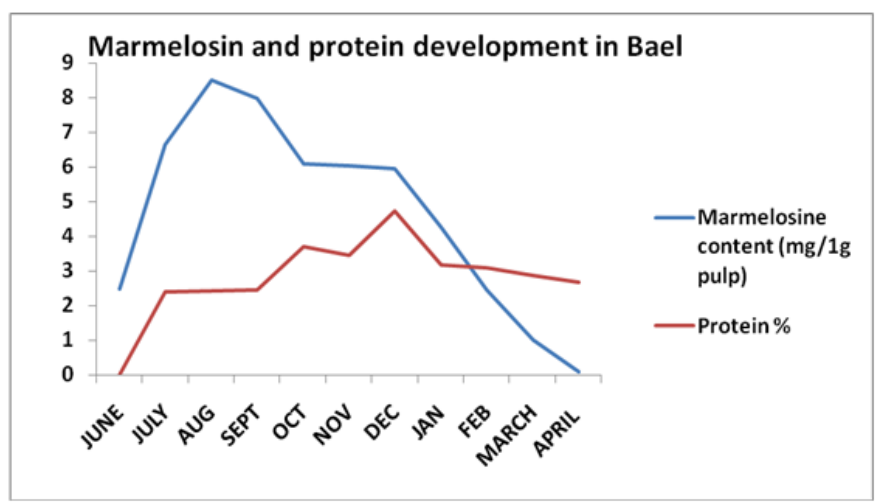

Figure 2 Protein and marmalosin content of bael during fruit developmental stages (FDS).

In other crops, guava (Psidium guajava). the fruit fly incidence was maximum between themonths of August and October under Dharwad area in Karnataka, India. ${ }^{22}$ In rain-fed ecosystem of Jharkhand fruit borer incidence was 6-10\% during August-October when poly-phenol content of the fruits gets decreased. At this period, these insects lay eggs on smooth surface of the lemon shaped bael fruit. When hatched, these fruit borers penetrate the fruit epidermis and caused $40 \%$ damage to the fruits. Moderate infestation about 6-10\% (3 points scale) by the fruit borer showing symptoms of fruit browning and subsequent dropping along with moisture and nutrient stress paved the way for at the tune of $40 \%$ total damage at fruit maturity. Infestation between $0-5$ per cent ( 2 points scale) by the fruit fly did not reduce the economic yield of the fruit crop. At 90 days growth period when the poly-phenol content was the maximum, the fruits showed considerable resistance to pest incidence and biotic stress in the late rainy season under Jharkhand, eastern India (2013). 


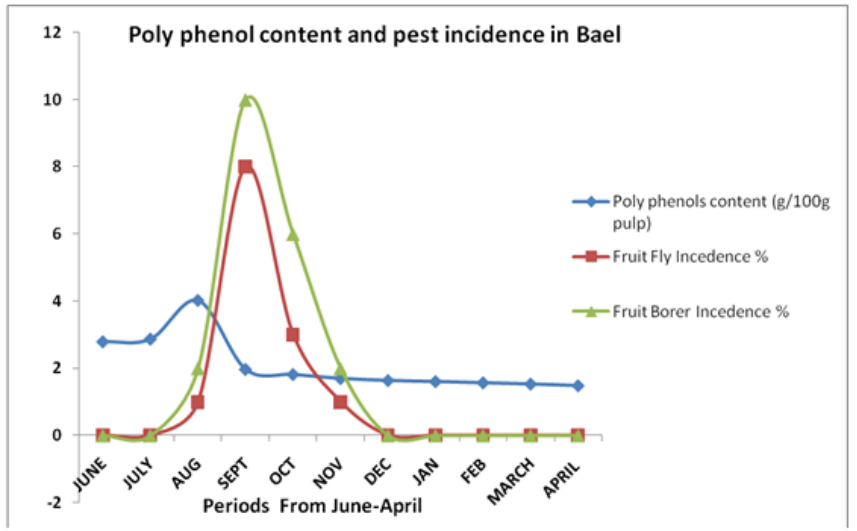

Figure 3 Polyphenol content and disease resistance in bael (FDS).

Fruit borer incidence 3= 6-10\%; Fruit fly incidence 2=1-5\% [3 months (avg.) Aug.-Oct.]

\section{Conclusion}

The present study was an attempt to analyze the different properties of bael fruit pulp to find out the future perspectives of this fruit. Mature bael had TSS of $26.0^{\circ} \mathrm{B}$. The maximum marmelosin content was $850 \mathrm{mg} / 100$ gram fruit pulp at 90 days growth periods. The pest incidence was maximum in August and September when poly phenol started decreasing. The reduction in poly-phenol during crop maturity paved the way for different sugar formation and flavonoids development accompanied by change in taste and aroma of fruit at final stage of harvest (April).

\section{Acknowledgements}

Authors are very much thankful to National Medicinal Plant Board (New Delhi)for their sponsored project on bael and Central Institute for Arid Horticulture" Bikaner, India for technical guidelines as one of the consortia partners and lead centre.

\section{Conflict of interest}

The author declares no conflict of interest.

\section{References}

1. Gupta, VK, Tandon R. Review on Indian medicinal plants. India: Indian Council of Medical Research; 2004. p. 1-312.

2. Sarkar S, Dash PK, Mannan A. Physiological characteristics and antioxidant assay of bael (Aegle marmelos) germplasm available in south western region of Bangladesh. J Bio Env Sci. 2015;6(9):26-33.

3. Singh DR. Underutilized Fruits Crops of Andaman and Nicobar Islands. Underutilized and Underexploited Horticultural Crops. In: KV Peter editor. India: New India Publishing Agency; 2007;2:11-54.

4. Kaur A, Kalia M. Physico chemical analysis of bael (Aegle Marmelos) fruit pulp, seed and pericarp. Chemical Science Review and Letters. 2017;6(22):1213-1218.
5. Prajapat RP, Gupta V, Soni B, et al. Extraction and isolation of marmelosin from Aegle Marmelos, synthesis and evaluation of their derivative as antidiabetic agent. Der Pharmacia Lettre. 2012;4(4):1085-1092.

6. Maity P, Hansda D, Bandyopadhyay U, et al. Biological activities of crude extracts and chemical constituents of Bael, Aegle marmelos (L.) Corr. Indian J Exp Biol. 2009;47(11):849-861.

7. Jana BR, Das Bikash, Singh M. Conservation and performance of some bael (Aegle marmelos Correa) genotypes under rain-fed ecosystem of eastern India. International Journal of Information Research and Review. 2014;1(12):133-135

8. Neeraj VB, Johar V. Bael (Aegle marmelos) extraordinary species of india: a review. Int J Curr Microbiol App Sci. 2017;6(3):1870-1887.

9. Singh HS, Sangeeta GS, rivastav K, et al. Emerging pest of fruit crops, like mango, litchi, bael, tamarind, sweet orange ,banana, papaya and guava in Eastern India. Journal of Applied Zoological Researches. 2014;25(2):161-169.

10. Ranganna S. Manual of analysis of fruits and vegetables product. India: Tata McGraw-Hill Publishing Co. Ltd; 1997. p. 29-31.

11. Thimmaiah SR. Standard methods of biochemical analysis. New Delhi, India: Kalyani Publishers; 1999.

12. Wheeler BEJ. An introduction to Plant Diseases. London: John Wiley and Sons Ltd; 1969.

13. Kumar D, Rajput CBS, Singh SP, et al. Survey of some important bael (Aegle marmelos) genotypes in Varansi region. Recent Horticulture. 1996;3(1):49-51.

14. Lakht-e-Zehra, Asadullah, Dar NG, et al. Nutritional exploration of leaves, seed and fruit of bael (Aegle marmelos L.) grown in Karachi region. Pak J Biochem. Mol Biol. 2015;48(3):61-65.

15. Laddha CS, Kunjalwar SG, Itankar PR, et al. Nutritional and phytochemical assessment of wild edible fruit of Aegle marmelos (LiNN) used by the tribes of bhiwapur Tasil Nagpur district, India. Asian Journal of Pharmaceutical and Clinical Research. 2015;8 (1):76-78.

16. Roy SK. Bael. In: Fruits: Tropical subtropical. TK Bose, et al. editors. Naya Prakash, India; 1998. p. 740-756.

17. Singh, Anurag, Sharma, Kaushal HK, et al. Bael (Aegle marmelos Correa) products processing: a review. African Journal of Food Science. 2014;8(5):204-2015.

18. Gopalan C, Ramasastri BV, Balasbramanian. Nutritive value of Indian foods. National institute of Nutrition, India: ICMR; 2000.

19. Roy, Deepti, Mishra KK, Mishra N. Labhkari Bael. Phal Phool. 2001. p. 26-27.

20. Kaushik RA, Yamdagni R, Dhawan SS. Physico-chemical characteristics of Bael fruit at green and ripe stage of maturity. Haryana J of Horticultural Sciences. 2000;29(1\&2):44-45.

21. Roy SK, Singh RN. Studies on changes during development and ripening of Bael fruit. Punjab Horticulture Journal. 1980;20(3):190-197.

22. Rajitha AR, Viraktamath S. Monitoring of Fruit Flies (Diptera: Tephritidae) in Guava Orchard at Dharwad, Karnataka. Karnataka J Agric Sci. 2006;19(1):45-49. 